\title{
THE KOREAN INSTITUTE OF INTERNATIONAL STUDIES
}

In zwangloser Reihenfolge erhalten an dieser Stelle Institutionen, die für die Entwicklungspolitik und Entwicklungsforschung von Bedeutung sind, Gelegenheit zur Selbstdarstellung.

The Korean Institute of International Studies was founded in 1965 under the auspices of Seoul National University (SNU) and until 1969 was funded by the university. In 1969 KIIS separated from SNU and became an autonomous, non-profit, independent academic body entirely supported by private financial contributions. The primary aim of the institute is the promotion of multinational and interdisciplinary research in the fields of peace and development.

All policies and decisions regarding KIIS are made by the Board of Directors, drawn from the Korean academic community and headed by Prof. Chong-Ki Choi of Seoul National University, the President of KIIS. A Board of Trustees, composed of leaders from the Korean business and journalistic communities provides financial support although they have no influence over institute policy.

In an effort to secure widespread international support for the objectives and activities of KIIS, in 1970 an International Advisory Board was formed and at present its membership includes some of the most distinguished scholars in the field of international relations from approximately twenty nations.

KIIS encourages discussion and cooperation among researchers within and outside the Republic of Korea by conducting seminars and conferences. It further provides training programs and sponsors public lectures of an international character. The Korean Institute of International Studies has conducted seven international conferences bringing together scholars from nearly every area in the world including Easter Europe and North America. The most recent conference entitled, "Search for Peace: Alternatives to Confrontation in East Asia", attracted a wide range of distinguished international scholars from diverse fields who discussed future trend in East Asian political, economic and social development.

More personalized seminars have also been sponsored by KIIS, drawing over one hundred foreign scholars to Seoul for wide ranging discussions with their Korean colleagues. Recent seminars have been conducted on such topics as strategic arms limitation, peace research in Japan and the future of Korean-Japanese relations. In addition in cooperation with UNESCO a conference devoted to investigating and increasing the effectiveness of international relations and peace research curricula in Korean Universities is presently being planned.

The KIIS library serves as a clearing center for research materials and data from abroad which enable Korean scholars to obtain current information in the field of international relations which would not otherwise be available to them. To contribute effectively to the study of peace and development KIIS welcomes the opportunity to establish joint research projects in cooperation with institutes abroad. At present KIIS conducts material exchanges with over two hundred insticutes and organizations throughout the world and is actively engaged in an attempt to expand this program. 
The facilities of KIIS are open to visiting scholars, researchers and students from overseas and KIIS will act as a host to assist them in their research efforts.

The institute's English quarterly, The Korean Journal of International Studies, and some occasional papers are available for circulation. The journal, established in 1970, strives to act as a forum for discussions on peace research and international relations, with particular, but not exclusive emphasis on the East Asian region and is the oldest journal of its kind in the Republic of Korea.

KIIS welcomes the submission of manuscripts on all aspects of contemporary international relations, particularly those in the fields of peace research and development.

Manuscripts typed in double space should be submitted, together with a duplicate copy, to the Editorial Board of the Institute. Contributors to recent issues of the journal have included: John W. Burton, Johan Galtung, Vlado Benko and G. K. Kindermann. Upcoming issues will be devoted to multidisciplinary analyses of South and North Korea since the Korean War. A special issue on East Europe is also anticipated at this time.

The opinions expressed in all articles and reviews in the journal are those of the contributors and should not be construed as representing those of KIIS.

Individual subscription rates may be obtained for US $\$ 15$ a year or US $\$ 5$ per copy. The institutional and library subscription rate is US $\$ 20$ a year. Back issues of the journal are also available. Foreign currency at the official exchange rate will be accepted.

At present KIIS is highly interested in expanding its relations with organizations of a like nature and would be particularly interested in initiating exchanges of materials and personnel. All inquiries, subscription requests and other correspondence should be sent to the Korean Institute of International Studies, KPO Box 426, Seoul, Korea: Cable Address, 1234 Seoul, Korea. 